\title{
Surveillance An Agenda for Latin America
}

\section{Nelson Arteaga Botello}

Faculdad de Ciencias Políticas, Universidad Autónoma del Estado de Mexico, Mexico. arbnelson@yahoo.com

\begin{abstract}
The objective of this paper is to demonstrate - albeit in a modest way - the conditions that have hampered the development of surveillance studies in Latin America. To do this, first of all, the paper reflects from a theoretical perspective on the processes through which the traditions of social science research are produced, with the aim of understanding, secondly, how studies of public security in Latin America are produced. In the third part, the paper shows how these studies establish a logic of research that sidetracks the importance of surveillance as a specific field of research. Finally, the paper suggests a need to develop surveillance studies in the Latin American region, with the goal not only of helping to build a particular field of research, but also to initiate a strong critique of the contemporary problems and limits faced by the tradition of studies on public security.
\end{abstract}

\section{Introduction}

Studies of surveillance have developed in a significant way in the last few years. As Klauser (2009) states, it has become a fertile field, which explores the implications of surveillance from different social science perspectives, in particular sociology. In general it can be said that an institutionalization exists in different academic spaces of surveillance studies. In Latin America these types of studies have not acquired an important significance. This is due to various factors, among others, the fact that the largest academic production of surveillance studies is in a language other than Spanish and Portuguese, or that access to this body of work is difficult for academic institutions to acquire due to the cost of subscriptions to specialized databases such as ISI Thompson, EBSCO and Proquest.

However, other reasons can be explored - maybe stronger and more significant - that refer to the interests of the academic world in the Latin American region, which, in some cases can be found linked with interests in both social and political participation. In order to understand the limited development of surveillance studies in Latin America, it must be viewed with a logic that responds more to access to academic work in the Anglo-Saxon world and with reference to a body of research with which surveillance studies has a "natural link" (Lyon 2007): such as policing and crime control.

Specifically, during the 1990s in a large part of Latin America there was a significant expansion of criminality, as well as an increase of the feeling of insecurity in the population. As an answer to this scenario there are not only policies of crime control and police action strategies, but also an important line of study in universities and research institutions, which shows, as a result, a developing number of thematic publications in magazines and specialized books. This has generated a field of research that, from 
different perspectives, tries to take into account the conditions in which delinquency and criminal violence emerge and reproduce in the different countries of the region, as well as the way in which citizens confront and generate them. Consequently, it can be said that studies on public security have been consolidated with a tradition of studies of diversity in research, some of which converge and others oppose, but what they have in common is the analysis of policing and crime control from disciplines such as political science, anthropology, communication studies, public administration, criminology, urbanism and history, just to mention a few.

However, in Latin America, studies on security have not been accompanied with studies on surveillance, despite their "natural" link. As stated by Lyon (2007), the word surveillance has a very narrow affinity with policing and to what is known today as crime control. If this is true then some important contributions to surveillance studies coming from policing and crime control, such as the work of Marx (1988), refers not necessarily to the same field of study. However, the question here would be why is surveillance studies not considered a relevant theme in public security studies? Especially in a context where the increase in crime and violence would make it feasible that studies of surveillance would be considered a main concern and developed as a specific field. In this article, two answers to this question will be proposed, which in some form can be linked together.

The first refers to the fact that the construction of recently consolidated traditional security studies does not include surveillance as a theme, it is considered as an element that depends on the analysis of security and the police. The second - linked in some way with the first - will show how the political and social actor's own interests, which finance the research in public security, focus on displaying more and better surveillance mechanisms, without ever discussing the implications that this will have on the population. It is evident, in both cases that there is a naturalization of surveillance that prevents the constitution of an object of their own investigation, contributing, as a consequence, to their dissolution as a relevant social phenomenon.

The objective of this article is to show the conditions that have not permitted the presence of surveillance studies in Latin America. For this, in the first instance, it is reflected from a theoretical perspective close to the process through which the traditions of social science research are consolidated, with the goal to understand, in a second moment, how the studies of public security in Latin America are consolidated. In the third part, the objective is to show how these studies establish a logic of research that sidetracks the importance of surveillance as a field of specific research. Finally, the necessity to include surveillance studies in the Latin American region will be suggested, with the goal of constructing not only a field of particular research, but to open a solid critique of the problems and limits which are faced today in the tradition of studies on public security.

\section{The Logic of Traditional Research}

Following the reflections of Alexander (1998), the development and crisis of social research should be understood as lines of explicative tradition which function as critical units of analysis and seek the accumulation of knowledge of a specific area in what is social. However, social knowledge advances and declines in a distinct form to the sciences referred to as "hard". Research programs, in this form, should be understood as a continuing scope of general, abstract and metaphysical reflections on one hand; but have a concrete, empirical and factual face on the other (Alexander 1998). In general, social scientists usually accept a formulation or an approach without solid and definitive evidence - in the natural scientific sense but do not accept a position without an argument and a vigorous strength of intellectual persuasion.

The social sciences, and in particular sociology, can be understood as collections of traditions, which regularly are referred to as schools (Alexander 1998). In this way, it can be defined as a rational-pragmatic discourse in distinct multi-levels. This discourse is pronounced close to society and its constituent units, 
with patrons and directions that are determined by distinct traditions of the social science disciplines. The elements of this definition, as Alexander (1998) argues, form a paradox and not a contradiction, in the way in which the traditions are patterns of perception and behavior which follow, in the first instance, not its intrinsic rationality, but their inheritance in its past:

The traditional status of social scientific schools confers upon them prestige and authority, which is reinforced because they are typically upheld by organizational power and supported with material resources (Alexander 1998: 33).

Similarly, the schools of research and their traditions define their theoretical nucleus, very resistant to change; but the areas that they surround - which in some cases are substantial - are found in constant change. In typical-ideal terms, the changes in peripheral zones of the theoretical nucleus of the traditions or research can be conceived "as proceeding along three lines: elaboration, proliferation and revision" (Alexander 1998: 34). These three profiles emerge periodically in the history of a tradition. After an immediate charismatic foundation there follows a period of ritualization, but in the awakening of a powerful reformulation, that must emerge if a tradition is to remain intact (Alexander 1998).

The reconstruction of science, on the other hand, results in explicit differences towards tradition, with such decisions being open to other traditions as well. The reconstruction can revive a theoretical tradition; it can even create an opportunity so that new traditions may be born. Traditions, however, can also be deconstructed. This does not happen as a result of the distortion of the nucleus or its peripheral zones, but due to the fact that its commitments have been de-legitimized in the eyes of the scientific community. In this sense, de-legitimizing implies the withdrawal of trust from the commitments of the nucleus.

Elaboration, proliferation and revision do not describe the development and real degree of scientific progress in Social Sciences. A new theoretical approach, for instance, requires a change in scientific sensibility and setting out for discussion different issues and adding a fundamental priority in the creation of different discourses. In this sense, according to Alexander (1998), it must be referred to as "social scientific movements" more than "social scientific development". Hence, the principal motor of scientific change is pragmatic: conflict and competition among traditions. Regularly, competition between schools is under-estimated, but the role that it plays is quite stimulating within the framework of activity regarding research programs.

Competition occurs in two discursive genres and among traditions. The first type has to do with the disputes within the interior of a tradition, with its residual categories, the analytical and empirical range. The second type occurs in the level of programs of research; a competition that is organized around the attempt of the rivals to explain the empirical structures and the processes linked to the analysis of tradition or the school of research. Certainly, it is important to point out that as Alexander (1998) states: a tradition moves forward when the topics of its declarations are judged as relatively superior, or compared to the research work produced by other schools. The best defense of a tradition under attack resides in articulating and defending the analytical bases of its research program. As expected, the competition generates winners and losers (Alexander 1998: 42). This process is fundamentally sociological more than epistemological, since competing implies an important mobilization, not only of intellectual and argumentative resources, but also of material and particularly economical ones, which allow the consolidation of research programs.

However, Alexander suggests that despite competition, bridges of communication exist that allow both winning programs as well as loosing ones interchange points of view, ideas, reflections, criticisms and arguments about themes that are relevant, both within each tradition, residual categories, the analytical and empirical range, as well as in the level of research programs. This interchange allows the introduction of aspects that in the beginning were not relevant or that were residual between competing programs. Placing 
points about what should be thought about and worked on opens the possibility that two disputed programs can find common ground, strengthening and stimulating the development of common research lines. Thus, the loosing program for example, can find a particular niche while the winning program can modify its original approach and amplify with it its lines of research. In this sense the logic of competition can not only be resolved by the elimination of one of the parts, but through its articulation. This can be seen when the discussion touches aspects that have to do with policy values considered relevant in modern society, such as liberty, privacy and civil rights among others. In general, when these aspects appear in the debate, Alexander (1982) suggests that it can plant a negative Hegelian strategy, more than the negative abstract: if one opposition is abstract to the position, then it negates it, if the opposition to the position is correct, it not only negates it, but also incorporates it to a certain point. This way, different perspectives of the social investigation can be articulated.

If we follow Alexander's (1998) line of argument, we could visualize that in the past 18 years, studies about public security have gone from a foundation or creation process to a status of proliferation, where despite the existence of different theoretical and methodological trends, their consolidation as a social scientific movement is evident, legitimizing a scientific sensitivity reflected in the institutionalization of centers of research and universities. Their development has not been easy, since it has implied the defying of other forms of interpreting security - normally related to studies of legal matters, for instance - which had a monopoly over the topics related to public security. The consolidation of public security studies took place little by little, from the emphasis that studies of legal matters where not sufficient to explain and understand the increase in criminal violence in a way that does not worry actors and social groups and the conditions of social transformation, among other aspects. Accordingly, public security studies, where articulated to legal studies, were later to acquire larger autonomy. In some way surveillance studies can, in the first place, begin by articulating to public security studies showing those aspects and themes that are of little relevance or simply residual. This would allow advancement in the strengthening of surveillance studies on public security, making aware the blind spots in their approach and lines of investigation. In the same way, it would allow studies of surveillance to acquire first a visibility that is still very weak in Latin America. The second thing is setting the foundation, consolidating them as independent research programs, with their own citizenship cards. To reach this, the ability to problematize is required, something that is not normally done with security studies - how surveillance devices significantly modify the framework in which the values of society move, even in an incipient way in the democracies of Latin America.

\section{Studies on Public Security}

Studies on public security in Latin America have been developed as a school that has created a young tradition of social research. Once democratization processes were spread within the region, the problems of public security started to consolidate as a relevant topic of social research in the 1990's. By the way, this was not a response to an exclusive intellectual itch: the criminal indeces began to increase considerably in Latin American societies (Rico and Chinchilla 2002). Mainly because the authoritarian systems, which strengthened in the region - in some cases with military dictatorships such as Argentina, or in other cases with single party governments as in Mexico - until they formed democratic institutions. However, this transition far from being exempt from difficulties, has generated a scenario of institutional emptiness, where the old practices have not disappeared and the new ones have not quite consolidated, thereby impacting directly the regulation and control of crime; democracy, paradoxically, appears to take away the capacity of coercion of the State (Hinton 2006), often leading to a scenario in which a "firm hand" is needed to end the high rates of criminal activity, typically by using the military and employing "zero tolerance" policies (Peralva 2001; Bodemer, Kurtenbach y Meschkat 2001). On the other hand it is important to state that the democratization process was accompanied by, as Wacquant (2008) points out, the conjunction of abysmal inequality with grossly inefficient or, sometimes nonexistent public services and massive unemployment in the context of a polarized urban economy, converting the scourge of 
countries and cities in Latin America, a condition that only exacerbates delinquency. Some studies have shown that in a majority of the countries in Latin America, armed violence - as perpetrated for example, by armed groups and gangs - has occurred where political institutions and public security providers suffer from: weak governance; alternative forms of political authority and security delivery; social crisis or malaise; macroeconomic distortions and political disorder; inequity; and a growing urban population, particularly in Central and South American countries (Geneva Declaration Secretariat 2008). However, poverty in and of itself does not generate delinquency; rather, its increase is also related at least to two other factors. The first refers to a dynamic expansion of the forms of urban life and a secularization of values, along with rules which regularly accompany this process (Romero 2000; Binford 1999; Vilas 2001; Handy 2004), and also is linked with the emergence of a series of new cultural and symbolic forms; the second refers to the construction of new subjectivities in regards to crime and violence.

In that sense, towards the end of the $1980 \mathrm{~s}$, it was possible to observe a significant increase in criminal violence in Latin America; in fact between 1990 and 1995, 60\% of its population was victim of some type of criminal offense (Del Olmo 2000). In Argentina, for instance, the number of offenders has duplicated between 1990 and 1999 (Pegoraro 2000), meanwhile the rate of delinquent acts for each 10,000 inhabitants in 2004 reached 343.0, and in 2005332.0 (Ministerio de Justicia, Seguridad y Derechos Humanos-República Argentina 2008). While in Mexico, the criminal rate totaled 1,000 crimes for each 100,000 in 1990; it reached 2,500 crimes for each 100,000 inhabitants in 1998 (Ruiz 1997); the rate per 100,000 inhabitants of recorded an increase in crimes to 1,391.5 in 2000 (UN Office on Drugs and Crime, Division for Policy Analysis and Public Affairs 2001). In Guatemala criminal offenses rose almost 100\% between 1995 and 1998 (De León; Rosa; Ogaldes y López 1999), reaching 239.63 per 100,000 inhabitants of recorded crimes in 2000 (UN Office on Drugs and Crime, Division for Policy Analysis and Public Affairs 2001), while in Nicaragua, crime against people and property duplicated between 1992 and 1996 (Saldomando 1999). In regard to the perception of crime in Latin American countries, in 2005 the percentage increased to $82.68 \%$. During the same year, in Argentina, this same indicator rose to 84.75\%; in Mexico, it reached 77.76\%; in Nicaragua it reached 92.49\% (Inter-American Development Bank 2008).

In contrast, in Europe crime rates have fallen. In the case of the United Kingdom, an important fall in recorded crime was registered during the nineties (Hicks and Allen 1999). In terms of violence, 60 per cent of all homicides in the world are committed with firearms, but in Central America, for example, the number rises to 77 per cent; while in Western Europe it represents only 19 per cent (Geneva Declaration Secretariat 2008). During the year 2000, average homicide rates worldwide were about 8.8 for every 100,000 inhabitants. By that year Latin America registered 19.3 homicides for each 100,000 inhabitants, while in Europe, the figure only showed 8.4 for each 100,000. More recent figures from the UNDP indicate that Latin America turned into one of the most violent regions in the world by registering 25 homicides per 100,000 people (Taniguchi 2011). In contrast, Western and Central Europe have the lowest levels with numbers below 3 homicides per 100,000 people (Geneva Declaration Secretariat 2008). For instance, Central and South America have similar homicide rates to Africa. These homicide rates show that in Latin America, violence plays a large part in the five main causes of death, and that in some countries such as Brazil, Columbia, Venezuela, El Salvador and Mexico, it is the main cause of death (Romano 2005). Violence in Europe, however, has decreased in the last few years, with its peak being reached in 1995, according to the International Crime Victims Survey (2008). In the ten years afterward there has been a decrease in crime in such a way that in 2005 it returned to levels seen in 1990 (van Dijk et al 2005). From the beginning of the eighties until the middle of the nineties, the murder rate increased $50 \%$ (Romano 2005), precisely in the years of transition from authoritarian governments to those with a more democratic nature.

According to Londoño y Guerrero (1999), urban violence in Latin America gets to represent a net cost in the order of $12.1 \%$ of the GDP making up 145 billion dollars a year; for the year 2007, the lost product due to violent deaths rose to 10,133 USD million, approximately $32 \%$ of the GDP of lost production was 
due to violent deaths (Geneva Declaration Secretariat 2008). Even in Central American countries, which lived in armed conflicts during the Cold War, the rate of death caused by criminal activity was actually higher than during those periods (Chinchilla 2005). ${ }^{1}$ In this region, the patterns of violence previous to the internal conflicts have been multiplied: from the trafficking of drugs and arms, to youth gangs, kidnappings, money laundering and homicide. In Central America, during 2004 the rate of homicides rose to 30 for every 100,000 people, $77 \%$ of those committed with firearms (Geneva Declaration Secretariat 2008). In this region of America, until 2005, the most violent countries were: El Salvador with 3,778 homicides 11.5 per 100,000; Guatemala, with 5,338 homicides, 8.0 per 100,000; Honduras, with 2,417 homicides, 5.0 per 100,000; Nicaragua, with 729 homicides 2.2 per 100,000 (Geneva Declaration Secretariat 2008).

In fact, towards the middle of the 1990s, when the expresions of criminal violence in the region reached their peak, the rate of homicides reached 28.4 for each 100,000 people, only less than the rate of SubSaharan Africa, which reached 40.1 (Morrison; Buvivnic y Shifer 2005). For 2004, the rate for Central and South America moved between 25 and 30 homicides for every 100,000 persons, while in South Africa, the rate reached close to 35 (Geneva Declaration Secretariat 2008). The five countries of Latin America with the highest rate of homicides are Columbia, Venezuela, Bolivia, Ecuador and Brazil; while the three with the lowest rate of homicide are Chile, Peru and Panama (Hinton 2006). The data on victimization is also a sample of the level of increase in criminal violence and offers - in a majority of cases - valuable information that could allow the problem of "black figures" of criminality to be resolved. According to the most recent data from the region, all of the countries of Latin America showed rates of victimization above $20 \%$, a majority above $30 \%$ and $40 \%$, and five of those between $40 \%$ and 60\%: Guatemala, El Salvador, Venezuela, Mexico and Ecuador (Rico y Chinchila 2002). According to the 2008 Latinobarómetro report, the rate of victimization in the region is 33\% (Latinobarómetro 2008).

Academia has tried to understand and explain these different expressions of insecurity from perspectives that highlight - in a different way and with different weight - not only the causes of the increase in offenses and crime in the region, but also the police strategies and public policies directed to end it. Several of these analyses certainly do not complement each other in the way in which they are inscribed in an academic environment, marked by the lack of theoretical and methodological consensus to approach the issue.

However, nowadays it could be stated that an important number of works on the topic of security exist, despite this diversity and plurality of perspectives. Such work demonstrates the awareness of the problem regarding policing and crime control at different levels and scales. Even so, most of these studies are focused on the analysis of social conditions, particularly on inequality, exclusion and poverty, which work as the backdrop that makes possible the emergency of security. Evidently, even though in most of this work there may not be a necessary relation between variables of analysis and delinquency, the truth is that the supposed link between insecurity and poverty (or inequality) has marked, as stated by Caldeira (2000), an important number of studies in the region of Latin America.

A second type of work is focused on the testing of security, as a result of the rupture processes within the traditional forms of coexistence and negotiation of conflicts, either as a general tendency in society or in reduced coexistence spaces, such as popular neighborhoods and rural communities. The works that look to explain how insecurity can be understood as a process of rupture of community links are inscribed in this line of investigation. In these types of work, the persistence on the studies of lynching is highlighted.

A third line of studies on public security is focused on analyzing the dynamics of expansion of new

\footnotetext{
${ }^{1}$ It turns out to be meaningful that during 2006, the main cause of death in El Salvador was "aggresion with the firing of another weapon”, causing a total of 2,793 deaths. Dirección General de Estadísticas y Censos. El Salvador. http://www.digestyc.gob.sv/
} 
cultural and symbolic forms, as well as the construction of new subjectivities in regard to insecurity: that has been referred to on some occasions as expressions of popular culture (Aparecida 1996). These types of work are directed to fundamentally analyze the youth gang phenomenon, as well as the culture of criminal violence (Briceño et al 1997). Finally, studies on public security have been an important contribution to the analysis of urban spaces, particularly on how insecurity and crime have encouraged social and spatial fragmentation in Latin American cities. The isolation of certain areas of the population from the general city environment due to fear and risk of becoming victims of delinquency has been highlighted in this type of investigation. This process has been considered as an expression of the culture of fear in Latin America (Pascual 2004).

In all these fields of research, somehow the position that the Nation-State has in societies of the region is emphasized. In general, it is understood that Nation-States have been a fundamental element to articulate the processes of insecurity self-control; in this type of analysis such processes are usually considered as part of the problem, since seen as incapable of establishing the minimum bases for citizens to live safely on their streets and houses (Waldmann 2003). This comes, paradoxically, with a high punishing load discourse. Research on the topic shows that normally in Latin America the State promotes disciplinary politics inscribed in the programs of attention to crime; the studies on the so-called politics of public security are in the same situation, whose design is based on the criteria aimed to re-construct the damaged legitimacy of the State in the region, which sometimes comes with the extension of a feeling of insecurity which strengthens the need to consolidate politics of public security.

In general, it is important to point out that in most of the public security study trends, the legal perspective has practically faded out, what remains is a vision directed at enhancing the social elements considered to be behind the conditions of crime and violence, but also the way in which policing and crime control are articulated, as well as the position of the State in front of insecurity. In this way, the studies on security have generated a proper space of research, institutionalized and with its own funds, which allow its survival and reproduction in the academic area in Latin America.

\section{The Blind Spot of Insecurity: Surveillance}

In most of the studies on security, however, the topic of surveillance seems to be largely absent. It is true indeed that the work done by Foucault are an obliged reference in many - of the studies about public security in the region, in general terms they are centered in aspects related to the discipline, the prison system and panopticism - in general, the locked up spaces, as well as its theoretical developments around the micro-physics of power. This treatment would leave the aspects that place surveillance as a relevant element in Focucault's perspective, on the periphery of reflection; they would be considered only as support for other topics, seen as more outstanding and meaningful. In the same way, this situation is repeated with the reading from Latin America to the works of Giddens. The studies about social structure in particular are taken from this author, and even more, his vision of contemporary societies in regards to organizational grouping, overlooking his perspective on the role of surveillance in the constitution of modern societies.

For that, when analyzing the organizational forms of police corporations, or the State in general in order to guarantee public security, it is determined that surveillance emerges from them - through the different devices (CCTV, biometric systems, among others) - as something "natural", intrinsic, therefore not requiring a particular scientific treatment. A reflection like this is connected specifically to the impact that these forms of surveillance have in the life of people and in the processes of negotiation, as well as in the administration of lives of the populations. Accordingly, surveillance in Latin America would be a topic that does not require any type of reflection, in the way in which it is inserted in the strategies of policing and crime control. 
Now, perhaps as a way to illustrate the topic, a personal anecdote may come in handy. Several months ago I was invited to participate in the writing of an article for a scientific journal coordinated by the National Network of Public Security, which is a group formed by the most prominent researchers on public security in Mexico. I sent an article that analyzed the social mechanisms implemented through the use of closed circuit television (CCTV) in two shopping malls located in Mexico City. The editors regarded the article as not prudent, under the argument that these types of devices did not require particular analysis since it is not relevant for social research. In this regard, they stated that in Mexico it could be considered as a novelty, something to be surprised about, but that at an international level it was not a relevant topic; CCTV's are not a topic of research, not even in developed countries, according to them.

Besides a story for a researcher's anecdote book, this fact should be considered as an example of the lack of interest, or even more, as a warning about the effects that current surveillance devices have in contemporary societies in Latin American countries. In this region, surveillance is understood as a merely technical problem, which does not require major attention and is considered as an "innocuous" device. Security research in Latin American countries does not explore the effects of surveillance, constituted as a form of social organization. When international organizations as well as public and private institutions of the countries of the region, finance studies on security, they place a special emphasis in the analysis of the conditions that allow delinquency to spread and expand. The proposals that are derived from such studies aim to highlight the need to perfect the security system in rural, urban and virtual spaces, as well as to perfect the action perspectives in the justice system and in the prisons.

Consequently, studies on public security - despite its diversity in perspectives - form a line of explicative tradition organized in accordance with a critic of analysis unit, consolidated in a specific social area, and allowing the accumulation of knowledge. In general, within the different countries of the region, studies on public security have formed an important theoretical reflection, with empirical studies provide solid legitimacy for this young tradition. This would permit, according to Alexander, discussion about study schools on public security. Hence, their status grants them not only authority, but also a certain prestige that reinforces with its institutionalization, organizational power providing resources in order to keep developing their analytical perspectives.

As a school of research, the central theme of studies on public security is organized crime as the cause of delinquency as well as governmental policies for combating it. All of these have left the issue of surveillance in the peripheral zone, and this oblivion has become routine. A change is required, in order to re-insert this element with the objective of generating a revision of a central approach that integrates studies on public security, both in regards to policing and crime control. Placing studies on surveillance would allow a change in the sensibility of the academic community in the region of Latin America; establishing new aspects in the topics of policing and crime control, and adding different voices to the academic discussion in this area. But this also allows highlights how the introduction of different surveillance devices modifies the framework in which some policy values linked to democratic societies move. The construction of large databases for public and private entities, as well as the use of diverse surveillance devices directed toward security and protection both by public and private entities, give a framework for the discussion of themes such as privacy, personal identity and social classification as well as the relationship between its own democracy, transparency, and the accountability with respect to collecting and managing of information. Also, additional themes have been dealt with by surveillance studies and only slightly by studies on public security.

In order to give potential to both surveillance and security studies, first of all, it would be beneficial to establish a bridge of communication between them through the development of coordinated lines of research. The first collaborations could begin to include surveillance themes which are found now in peripheral space. Such themes could be, for example, the implications of CCTV in the formation of urban spaces as well as the role of ID cards in social classification and the introduction of biometric systems as 
mechanisms of discrimination. But on the other hand, and maybe more importantly, surveillance studies could open a special development niche, form a firm denile as Alexander (1982) suggests, highlighting themes related to policy values that are at play with the introduction of surveillance devices in those still weak Latin American democratic societies. Values that regularly do not consider public security studies, in the way in which they worry more about explaining and understanding the factors linked to the emergence of criminal violence, organized crime, as well as the logistics of policing, crime control and how surveillance devices are considered as something necessary and natural as a mere technical aspect for facing crime.

\section{Surveillance and Security: An Analytical Synthesis}

The incorporation of surveillance research in studies on public security in Latin America allows, on one hand, the opening of a field of themes and topics that are presently found situated in a peripheral space; on the other, it would open the possibility to reflect on the modifications of the framework in which Latin American policy values are applied to democracy. This means that, in the first place, it not only places on the table of discussion themes such as the treatment and handling of surveillance devices, but also allows the accompaniment of a reflection on the way in which Nation-states in the region are found designing the implementation and managing of surveillance devices. Secondly, and maybe more importantly, it will allow the ability to weigh the impact that surveillance devices have in a democratic context where the presence of authoritarian practices persist, in which the mechanisms of transparency, accountability and regularization institutionalized from the conflicts is still a project that should continue. Finally, this could lead to surveillance studies being introduced to the political agenda, regional fundamental themes and points for the development of democracy in Latin American countries. In this way, the importance of research on surveillance stems not only on the necessity to focus a series of blind points in security studies, policing or crime control, but because it deals with themes which are relevant to give feeling to the project of Latin American democracy, both in the discussion of certain policy values which sustain functionality and administration of the political institutions in the region.

\section{a) Surveillance and Studies on Security}

Studies on security have centered their analysis, as mentioned before, on four lines of work. The first of these is oriented toward the analysis of poverty and social inequality as elements that serve as a backdrop for increased criminal violence. This has marginalized the importance of the analysis of personal databases directed both to classify who is found in conditions of poverty, as well as constructing criminological profiles from associating personal data with socioeconomic conditions - such as salary, education level as well - as spaces - with the type of living zone where they reside. These expressions of surveillance have effects on social life and should be located in the center of the discussion of surveillance research.

The second line of research on security studies is directed toward examining criminal violence as an expression of a break in the traditional forms of coexistence and negotiation of conflicts between social groups, as well as between the State and its citizens. The use of certain surveillance devices contribute to accentuating the process of breaking down the social fabric, introducing new points of conflict, as well as negotiating between social groups, citizens and the State. The third line of work on studies of security is oriented toward the understanding of new cultural and symbolic forms and new subjects in regard to insecurity. This line should consider that surveillance devices are also part of the cultural framework of insecurity: the population of the region considers that a place under surveillance is a secure place, demanding more and better surveillance devices such as the ones used in such places. In a region marked by inequality, surveillance is converted into a symbol of status, as a form of social recognition, in that 
security is considered a scarce benefit that few can have. A fourth line of study on security points to the examination of urban fragmentation, in particular the construction of closed spaces such as living zones, financial and commercial centers. Introducing some research on surveillance in the traditional points on security studies allows one to determine how surveillance devices are transformed into instruments that the administrators of such spaces use to control access to them, such as being in control of the mechanisms of socio-spacial social inclusion and exclusion.

In the different fields and analysis scales of surveillance that have been shown here, these topics are pertinent. The expansion of surveillance devices which during the nineties were disseminated along the entire breath of Latin America as a form of containing the feeling of insecurity and fear of the citizenry, provide the city with a face where social relationships are marked by spatial discontinuity, where "fields of security" seem to form and where citizenry is negotiated from the exclusion or inclusion of those who can stay in specific areas or not.

\section{b) Management of Surveillance}

Surveillance devices context should be repositioned as important elements in security studies, in the way in which they produce classification mechanisms or social sorting, that in many cases contribute to the production and reproduction of exclusionary processes and social marginalization. In particular, by demonstrating how security logic and surveillance is closely linked to the management of the population through the recollection of data and their transformation into information. As Lyon (2007) states, public entities, but also private ones, have as a priority, the collection of data and the handling of information as central elements in the management of the population. The control of crime and policing are strongly linked with the creation and administration of information, which allows the management of risks through algorithmic estimates (Lyon 2007). Surveillance both in a public and private environment needs to be fed constantly with data and information on individuals and social groups. In each one of the surveillance analysis scales examined here, this result is evident. It implies opening the discussion on transparency of the use of information and data that is in possession of the different instances of surveillance. As stated by Lyon (2007), there are three reasons that the theme of transparency and providing justification about the use of information that is obtained through surveillance. The first is that contemporary society and the State have an increasing appetite for personal data. The second is that the use of this data is allowing, in many instances, the organization and classification of individuals and social group, generating new forms of discrimination. The third is linked with the fact that information obtained from surveillance involves real people, of flesh and blood, over which actions can be taken against their dignity and liberty. In this way, the transparency of surveillance is vital for the health of democracy and human dignity (Lyon 2007).

A theme closely linked with transparency is who is in charge of driving it. In other words, this can be summarized with the question: who watches the watchers? And even more so: who establishes the categories that permit surveillance? These two questions are the center point in the sense that they demonstrate the opacity over the criteria of population observation, criteria that, in the last instance, define opportunities, mobility and insertion of persons in social life. If these are found based on prejudices, in stereotypes of who can or cannot be a delinquent, a drug trafficker or a legitimate consumer, individuals consider their citizenship limited. This worsens more in labor spaces that have a very strict surveillance structure: the relation of dominating employer over the employee is increased to the limits that can go against human dignity. Surveillance, in this sense can start to impose, as stated by Giddens (1985) totalitarian organizational rules of society, based on the administration and codification of the population's information, as well as in the supervision of their activities. Thus, it is vital to make surveillance mechanisms transparent and visible.

\section{c) Surveillance and Democratic Consolidation}

As stated by a number of surveillance studies scholars, the administration and governmental management of Nation-States can be found firmly linked to the expansion of different surveillance devices, in the way a 
routine form is made up of transactions between different governmental agencies and its citizens. In fact, European Nation-States entered into a rise of producing diverse data about its populations and its own administrative activities, above all in the nineteenth century (Hacking 1995). The most completed related device was, certainly, the implementation of national identity cards of a different type, with its immediate origins being from the nineteenth century (Lyon 2005). As Torpey (2000) points out, the registration of each citizen implies that they are embraced or grasped by the State for the purpose of extracting the information needed to guarantee its reproduction over time. It is therefore possible to consider the idea of a Nation-State with a territorial organization of its residents as being created not only for the purpose of controlling, but also for safeguarding them. This process of surveillance consolidation by governmental administrators also strengthened with the expansion of democracy in the twentieth century (Dandeker 1990). This resulted in a need to establish a base that guarantees the demands of equality and equity at the same time that it insures the pertinence of individuals in a determined citizenry.

Surveillance is therefore a substantial part of the construction of modern Nation-States, and at the same time a fundamental element for the definition of the idea of citizenship in democratic political systems. Through surveillance and collection of data, citizens can exercise a legal personality before the State and other citizens, having an identity for which they can be recognized, having a guarantee of the exercising of their rights and obligations, which allows them to demand protection of the State in certain aspects- such as health, education and unemployment. The State can largely satisfy the demands of equality and equity in which it has the capability to plainly identify those individuals who make these demands.

However, in the context of Latin American countries, where the establishment of democratic institutions is still recent, the implementation of different surveillance devices, as well as the capacity to organize and collect information on a large scale, can serve governments of the region for strengthening or reviving authoritarian practices. As a result, research on surveillance is relevant because it brings into consideration the dangers that different forms of surveillance imply, without defined criteria such as transparency and accountability with respect to the collecting and managing of information, and that directly affect the construction of democratic institutions in the Latin American region. Surveillance studies also raise themes that public security studies on public do not warn about because they focus on the analysis of the conditions on emerging criminal violence, as well as the impact of policies on public security. But what is also relevant for government authorities, who are obsessed with guaranteeing at all costs the security of the population, is not noticing the effects that the expansion of surveillance and collection of data can have in the future of the region's democratic institutions. Unfortunately it is possible to see that a good part of Latin American societies, each day more indulgent and non-critical towards surveillance, because they consider living under a permanent risk that represents criminal violence. This implies, as stated by Diken and Laustsen (2005), if a State or social institution transforms security into the essence of their legitimacy, a fragile organism is transformed: under the belief that one always remains under attack and may produce terror among its citizens, the State becomes the terrorist itself.

Surveillance, as an axle of the articulation of modern society cannot be expelled from our lives. However it does not imply that it may come in the way of citizen's rights. To know who watches, under what criteria and how this systematic observation is transformed into information, is a right that makes it possible that democracy does not transform. In the end, in a mere machine of social life management administered by experts that, under the slogan that everything could be a "risk", reproducing the social inequality through the classification, categorization, cataloguing and typification of individuals and groups. 


\section{References}

Alexander, Jeffrey. 1998. Neofunctionalism and After. Massachusetts: Blackwell Publishers.

Alexander, Jeffrey. 1982. Theoretical Logic in Sociology. Positivism, Presuppositions and Current Controversies. Berkeley: University of California Press.

Aparecida, María. 1996. Violencia, cultura popular e organizacoes comunitarias. In Velho, Gilberto y Alvito, Marcos (Eds.) Ciudadanía e violencia. Río de Janeiro: UFRJ-FGV.

Binford, Leigh. 1999. A failure of normalization: transnational migration, crime, and popular justice in the contemporary neoliberal Mexican social formation. Social Justice 26(3) 123-144.

Bodemer, Klaus, Kurtenbach, Sabine and Meschkat, Klaus. 2001. Violencia y regulación de conflictos en América Latina. Venezuela: Editorial Nueva Sociedad.

Caldeira, César. 2000. El crimen organizado en Brasil. Nueva Sociedad 167, 99-113.

Briceño, Roberto, Camardiel, Alberto, Avila, Olga, de Armas, Edoardo, and Zubillaga, Verónica. 1997. La cultura emergente de la violencia en Carácas. Revista Venezolana de Economía y Ciencias Sociales III(2-3) 195-214.

Chinchilla, Laura. 2005. Experiencias de participación ciudadana en la prevención del crimen en Centroamérica. In Fruhling, Hugo; Tulchin, Joseph. (Eds.) Crimen y violencia en América Latina 245-275. Colombia: Fondo de Cultura Económica.

Dandeker, Christopher. 2006. Surveillance and Military Transformation: Organizational Trends in Twenty-First-Century Armed Service. In Haggerty, Kevin and Ericson, Richard (Eds.) The new politics of surveillance and visibility 225-249. Canada: University of Toronto Press.

De León, Escribano, Rosa, Carmen; Ogaldes, Claudinne and Lopez, Claudia. 1999. Guatemala: diagnostico de la problemática posconflicto. In Violencia social en Centroamérica: ensayos sobre gobernabilidad y seguridad ciudadana. Managua: CRIES.

Del Olmo, Rosa. 2000. Ciudades duras y violencia urbana. Nueva Sociedad 167, 74-86.

Diken, Bülent and Laustsen, Carsten. 2005. The Culture of Exception. Sociology facing the camp. New York: Routledge.

Geneva Declaration Secretariat. 2008. GLOBAL BURDEN of ARMED VIOLENCE. United Kingdom: Paul Green Printing. Obtained September 14 2011, available at: http://www.genevadeclaration.org/fileadmin/docs/Global-Burden-of-ArmedViolence-full-report.pdf Giddens, Anthony (1985) The Nation-State and Violence. Cambridge: Polity Press.

Hacking, Ian. 1995. La domesticación del azar: la erosión del determinismo y el nacimiento de las ideas del caos. Gedisa: España.

Handy, Jim. 2004. Chicken thieves, witches and judges: vigilante justice and customary law in Guatemala. Journal or Latin American Studies 36(3) 533-561.

Hicks, Joe and Allen, Grahame. 1999. A Century of Change: Trends in UK statistics since 1900. House of Commons Library. Obtained September 12 2011, available at: http://www.parliament.uk/documents/commons/lib/research/rp9/

Hinton, Mercedes. 2006. The State on the streets: Police and politics in Argentina and Brazil. United States of America: Lynner Rienner Publishers, Inc.

Latinobarómetro. 2008. Informe Latinobarómetro 2008. Obtained December 15 2008, available at: http://www.latinobarometro.org/

Inter-American Development Bank. 2008. Data Bank. Obtained December 10 2008, available at: http://www.iadb.org/research/statistics.cfm?lang=en

Klauser, R. Francisco. 2009. 'Lost' Surveillance Studies: a discussion of French research on CCTV. Surveillance \& Society 6(1) 23-31.

Londoño, Juan and Guerrero, Rodrigo. 1999. Violencia en América Latina. Epidemiología y costos. Banco Interamericano de Desarrollo, Documento de trabajo R-375.

Lyon, David. 2007. Surveillance Studies: and Overview. Cambridge: Polity Press.

Marx, Gary. 1988. Undercover: police surveillance in America. Berkeley: University of California Press.

Ministerio de Justicia, Seguridad y Derechos Humanos-República Argentina. 2008. Base de datos. Obtained December 15 2008, available at: http://www.jus.gov.ar/

Morrison, Andrew, Buvinic, Mayra and Shifter, Michael. 2005. América violenta: factores de riesgo, consecuencias e implicaciones para las políticas sobre la violencia social y domestica. In Fruhling, Hugo; Tulchin, Joseph. (Eds.) Crimen y violencia en América Latina 117-151. Colombia: Fondo de Cultura Económica.

Pascual, Mayarí. 2004. Violencia y miedo urbano: reflejos de la ciudad de México. In Raquel Sosa (Coord.) Sujetos, víctimas y territorios de la violencia en América Latina. México: Universidad de la Ciudad de México.

Pegoraro, Juan. 2000. Violencia delictiva, inseguridad urbana. La construcción social de la inseguridad ciudadana. Nueva Sociedad 167 114-131.

Peralva, Angelina. 2001. Violence et démocratie. Le paradoxe brésilien. Paris: Balland.

Rico, José and Chinchilla, Laura. 2002. Seguridad Ciudadana en América Latina. México: Siglo Veintiuno Editores.

Romano, Ignacio (Coord.) 2005. Informe: El Ranking de la Violencia en América Latina. Fundación Fundar. Obtainded September $14 \quad 2011$

2011,

Romero, Bernardo. 2000. Notas para un modelo alternativo de seguridad ciudadana. Diálogo y Debate de Cultura Política 12 101-119.

Ruiz, Rafael. 1997. Inseguridad y mal gobierno. México: Sansores \& Aljure 
Saldomando, Ángel. 1999. Nicaragua: Los rostros de la violencia. In Violencia social en Centroamérica: ensayos sobre gobernabilidad y seguridad ciudadana, Managua: CRIES.

Taniguchi, Hanako. 2011. América Latina, una de las regiones más violentas: PNUD. CNN México. Obtained September 142011, available at: http://mexico.cnn.com/nacional/2011/09/14/america-latina-una-de-las-regiones-mas-violentas-pnud.

Torpey, John. 2000. The Invention of the passport. Surveillance, Citinzenship, and the State. Cambridge: Cambridge University Press.

UN Office on Drugs and Crime, Division for Policy Analysis and Public Affairs. 2001. Seventh United Nations Survey of Crime Trends and Operations of Criminal Justice Systems, covering the period 1998-2000. Obtained December 2008, vailable at: http://www.unodc.org/pdf/crime/seventh survey/7sc.pdf.

Van Dijk, Jan, Manchin, R., Van Kesteren, J., Nevala, S., and Hideg, G. 2005. The Burden of Crime in the EU, A Comparative Analysis of the European Survey of Crime and Safety. EU ICS.Obtained September 13 2011, available at: http://www .europeansafetyobservatory.eu/downloads/

Vilas, Carlos. 2001. (In) justicia por mano propia: linchamientos en el México contemporáneo. Revista Mexicana de Sociología 63(1) 131-160.

Wacquant, Loïc. 2008. The militarization of urban marginality: Lessons from the Brazilian metropolis. International Political Sociology (2) 56-74.

Waldmann, Meter. 2003. El Estado Anómico: derecho, seguridad pública vida cotidiana en América Latina. Caracas: Nueva Sociedad. 